\title{
Serpentine Tribotechnical Composition «Saranovsky». Preparation and Comparative Tests
}

\author{
AV Dunaev* \\ Federal Scientific Engineering Centre, Russia
}

*Corresponding author: Dunaev AV, Federal Scientific Engineering Centre, Doctor

Received Date: April 01, 2019

of Technical Sciences, Leading Research, Russia.

Published Date: April 30, 2019

\begin{abstract}
Non-traditional tribotechnics with the use of organic, metal and mineral tributechnical compositions allows for without disassembly repair of worn-out friction units of various civil and military equipment. From 1942 it developed a slow but with 2000 there were over 200 different tribological compounds, of which in Europe, Asia, America widely used a few dozen.

In Russia, due to the simplicity of preparation, application and efficiency, the most widely used powders of minerals of the serpentine group were found. Their creation and justification of application took place in the 80-90s years in St. Petersburg and many other research institutes of Russia.

Tribological studies of highly dispersed powders of the serpentine group minerals - magnesium hydro silicates Mg6[Si4010](OH)8 and similar, as well as performance testing of their application was carried out in the Nano Centre of research Institute GOSNITI. Here in the research serpentine compositions or geo-modificators friction conducted more than 5,000 tests 80 different songs, and in the center UNIITiN conducted operational testing tribotechnical composition, created Nano center GOSNITI.
\end{abstract}

In creating the serpentine tribotechnical composition in the Nano center GOSNITI waste is used flotation chrome ore Deposit mining facility. Powders were purified, subjected to heat treatment, mechano activation on a planetary ball mill ACTIVATOR 2SL, be-fore and after preparation was investigated on X-Ray diffractometer XRD 6000, and on an inverted metallographic microscope OLUMPUS GX 51. Laboratory tribotechnical tests of the finger-disc steel pair in engine oil with tribo-compositions were carried out on the TRB-S-DE tribometer in the step loading mode to a pressure of $218 \mathrm{MPa}$ at a sliding speed of $100 \mathrm{~cm} / \mathrm{s}$.

These comparative tests showed that the tribo-composition of Saranovsky in mineral motor oil of quality classes SS API and viscosity 30 SAE (manufacturer Russia) approximated its tribological properties to the best in the world motor oil firm Mobil to the coefficient of friction 0.04 .

250-hour performance testing in the center UNIITiN in three diesel engines of Rus-sian tractors showed a decline in fuel consumption by 5-8 \%, of oil burning on 10-12\%, the opacity of gases by 8-15\%, and iron content in oils by $20-25 \%$. This once again confirmed the known from the late 80-s years of the effectiveness of in-place repair of serpentine structures to increase their service life automotive engineering.

Summarizes the features of the building and tribological properties of serpentine coatings. From this it is assumed that the growth of the carbon-containing coating, even with the removal of the tribotechnical composition from the oil, is due to the activation of friction coatings and the unique properties of the atoms of the carbon, the possibilities of sp2, sp3 hybridization, chemisorption coatings of hydrocarbon lubricants, and in the interfaces to dry and also carbon dioxide environment.

Keywords: Physicomechanical properties; Pavement application; Rock aggregates; MRT specifications; Granite; Ghana

\section{Introduction}

In the last 30 years, the use of non-traditional tribotechnical materials has been expanding to effectively restore the functionality of worn-out friction units of various kinds, especially in Russia, Finland, Japan, Germany and China. Development of [16] and approbation [7-18], for example, mineral tribomaterials is expanding especially in Russia, and the overall diversity of tribomaterials (more than 200) is known in many countries of Europe, Asia, Africa, America. But in 2000, Russia moved Nano diamond triboactive [19], and in 2015 - there are Nano-sized carbon fibers (Russia).

Among the tribomaterials for repair without disassembly powders of serpentine group are particularly attractive due to the ease of preparation, application and efficiency. Their origin occurred in St. Petersburg in the 80-ies. [1,3,5], justification for use - in Institute Mechanobr [3], IMASH RAS [2], in many other research institutes, and the first experience in NPIF «Enion - Baltika», SPC 
«Ruspromremont» [13], NPTC «SUPRO-TEK», in dozens of other civil and military organizations of Russia, Japan, Finland, China, France, Germany, Egypt, Greece and other countries [7-18].

In the Nano center of GOSNITI, studies of serpentine «repairreduction compounds» or friction geo-modifiers (CFG) were also conducted and more than 5,000 tribo-tests of 80 compounds were conducted $[16,17]$

\section{Purpose of work}

One study in GOSNITI had the objective of creating a stable Mineralogy and tribologist repair-recovery composition from waste products of mining enterprises.

\section{Materials, devices and equipment used}

As raw materials used flotation waste mining plant of Russia. The primary ore consists (according to the research Institute of the Russian Federation «Giredmet», Russia), 95\% of chrome - spin elide-an industrial source of chromium and silicate, represented by serpentine, developed by pyroxene and rarely by olivine. And waste flotation on the chrome minerals (according to the same research Institute) consist mainly of mineral lisarditega bastita by orthopyroxene and appareling Lizardite $\{\mathrm{Mg} 3[\mathrm{Si2O5}](\mathrm{OH}) 4\}$. The waste could be a bit of chlorite, calcite and garnet with lesser content of chrome spinel (Mg,Fe)(Cr,Al,Fe,Ti)204.

In the preparation of triboactive in the Nano center GOSNITI used:

- $\quad$ electric Cabinet SNOL (up to $350^{\circ} \mathrm{C}$ ) for heat treatment of the initial powder,

- vibration screen «Analizzete 3Pro» (sieve 20, 25, 32, 40 and 100 microns) for powder classification,

- ball planetary mill «ACTIVATOR 2SL» for powder activation (powder $70 \mathrm{~g}$, steel balls $15 \mathrm{~mm}$ - 10 pieces, $10 \mathrm{~mm}-20$ pieces. and $6 \mathrm{~mm}$ - the rest up to 350 g.; duration of grinding 5 and $10 \mathrm{~min}$.$) ,$

- inverted metallographic microscope «OLIMPUS GX 51» to control the fractionation composition of the powders of the original and processed,

- X-Ray diffractometer XRD 6000 with a library of spectra «ICDD» to determine the phase composition of the initial and processed powders,

- $\quad$ tribometer TRB-S-DE with steel tribological pair «fingerdisk» in the mineral engine oil quality classes the SS API and SAE 30 viscosity (manufacturer Russia) in the mode of stepwise loading up to a pressure of $218 \mathrm{MPa}$, sliding speed $1 \mathrm{~m} / \mathrm{s}$, the friction path of $1500 \mathrm{~m}$

\section{Preparation and testing of triboactive «Saranovsky»}

The initial powder on a sieve of $1 \mathrm{~mm}$ was cleaned, dried for an hour at $105^{\circ} \mathrm{C}$, fractionated on a sieve of $100 \mu \mathrm{m}$ of a vibrating screen, subjected to grinding on a mill and repeated fractionation on a sieve of $40 \mu \mathrm{m}$. The type of the obtained powder from the vibrating screen is shown in Figure 1, and the microphotography of its particles is shown in Figure 2.

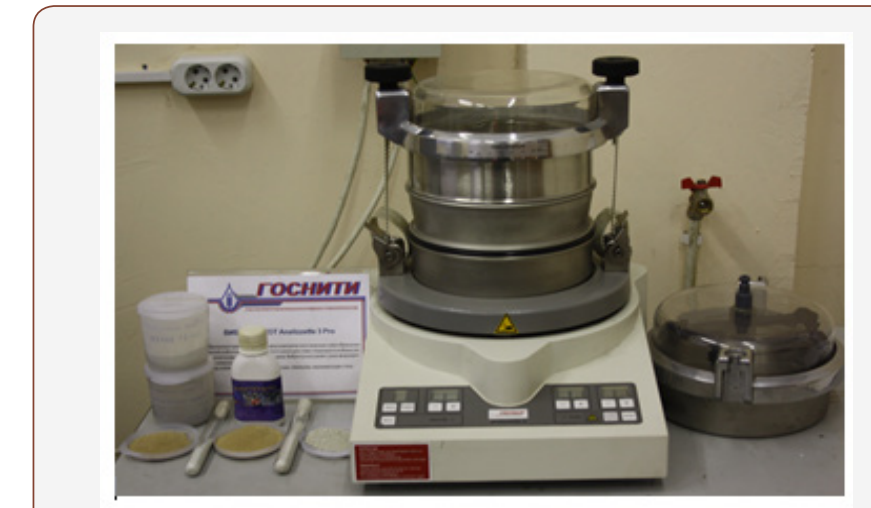

Figure 1: Fractionation of powders in a vibrating screen "Analysette 3 Pro»; the powder left is the original; in the center processed, it became lighter; right powder companies «IKSAR»; in vials tribo-active "Sarnowski» and «RVD»; in jars powders CFG from Georgia.

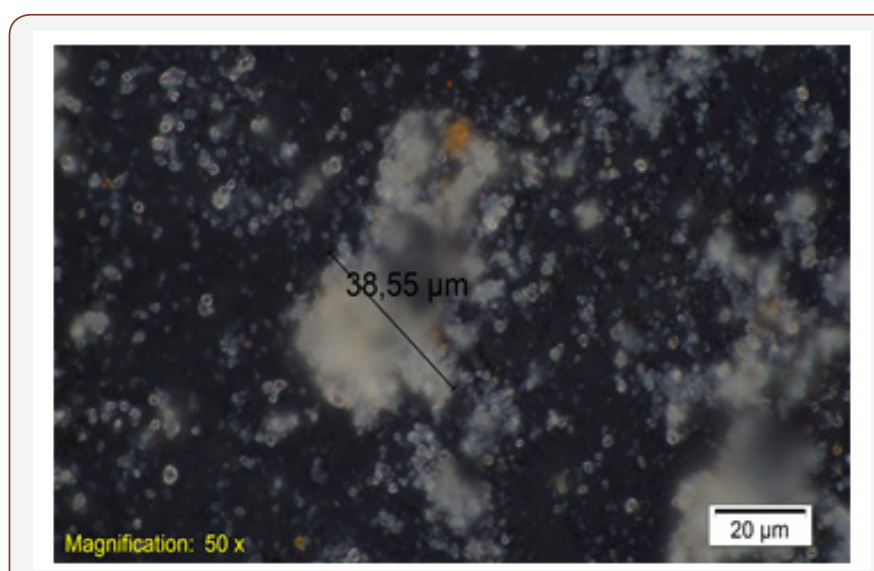

Figure 2: Microphotography of tribo-composition particles "Saranovsky» on the microscope OLYMPUS GX51.

\section{The resulting properties of the tribotechnical composition of the «Saranovsky»}

According to X-Ray phase analysis, the powder is a particle of the mineral Lyzardite - the main tribotechnical component of serpentine. Its crystals are formed in the mono clinic system. The color of the crushed powder is gray-yellow, the density is $2550 \mathrm{~kg} /$ $\mathrm{m} 3$, the hardness on the mineralogical scale is 2.5 .

Figure 2 shows, that a large fraction of the particles has a size of 1-5 microns, but there are rare agglomerates up to 40 microns. The average particle size is $2.3 \mu \mathrm{m}$. As for 30 -year-old practice, and on the other on a tribotechnical composition of the optimum particle size of 1-25 microns [2,10], tribalistic «Sarnowsky» for fractional composition is satisfactory.

The speeches of participants of the conference in RUSNANO 15.01.2009 and according to some publications $[2,5,7,10]$ chromium compounds to a tribotechnical composition to be harmful. Therefore, powders before and after grinding were subjected to diffractometry (Figure 3). 


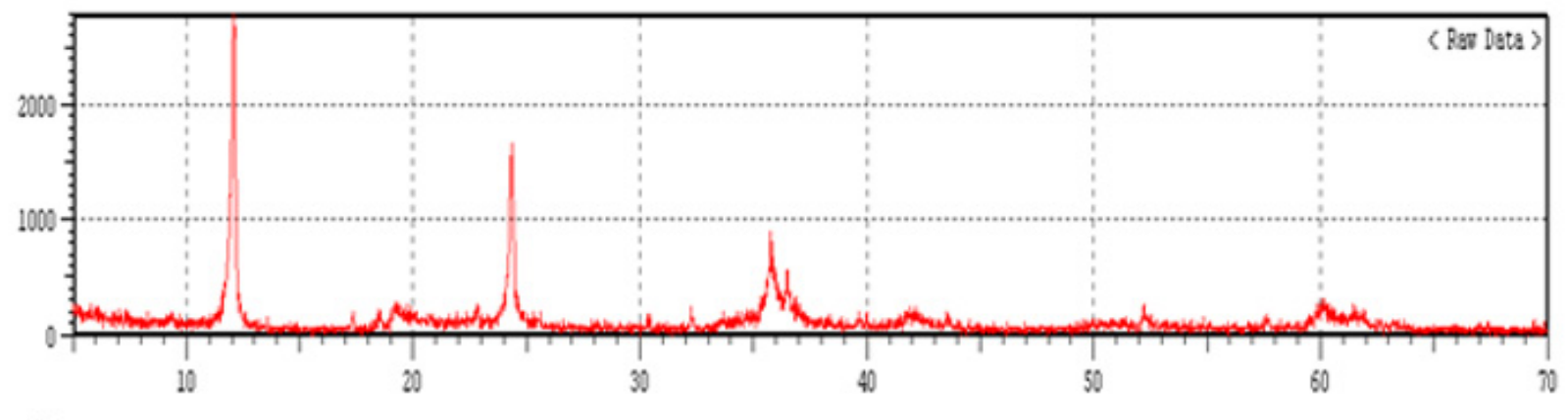

Figure 3: Diffractogram powder» of CFG «Saranovsky»: identified Lizardite-1T.

It was found, that of all the substances, when searching in the main volumes of the ICDD library, there are no chromium compounds in the CFG «Saranovsky», and, in the sequence of their concentration, revealed:

- $\mathrm{Mg} 3[\mathrm{Si2O5}](\mathrm{OH}) 4$ - Aluminum Iron Magnesium Si, Lisardite-1T - basic mineral of serpentine group;

- $\quad \mathrm{Ni3}[\mathrm{Si205}$ (OH)4 - Nickel Silicate Hydroxide, Pecoraite 2Mc1 - secondary serpentine group mineral, as an impurity;

- $\quad[\mathrm{Ni5}, \mathrm{Al} 4011] \cdot 18 \mathrm{H} 20$ - Nickel Aluminum Oxide Hydroxide-other impurity. It should be noted, that in parallel, the investigated CFG from Limited liability company «STANRUS» for «Wl-technology» [8] represented a mixture of more than 12 minerals, of which 2 - do not belong to the serpentine group minerals, 6 - are represented by aluminum hydro silicates, one is a jelly hydro silicate, one is a hydro silicate of mixed composition (iron, magnesium and aluminum) and only one is a hydro silicate of magnesium: Mg3[Si2O5](OH)4 - Magnesium Silicate Clinochrysotil.

\section{Comparative tribotechnical tests of CFG «Saranovsky»}

The test results of several tribo-compositions are shown in Figure 4.

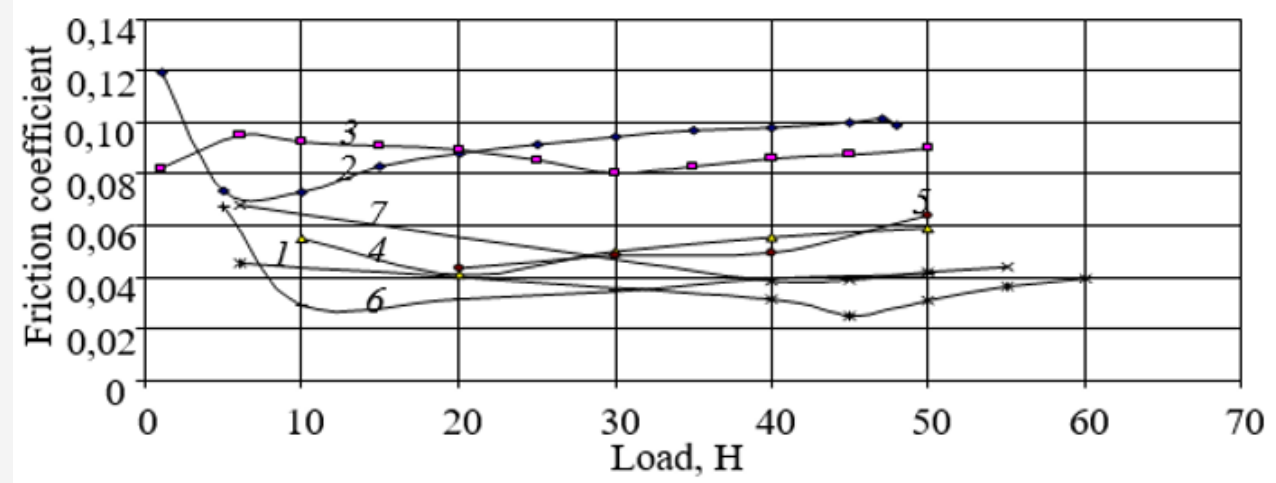

Figure 4: Friction coefficients steel tribological pair «finger-disk» in the motor oil Mobile SJ/SL API and 05W-30 SAE (1), as well as in motor mineral oil (2) and introduced in it tribological composition: preventive CAMP (3), serpentine CNT (4), MC-20 (5), «Saranovsky» (6) and nanodiamond KARAT (7).

Tribo-tests showed high load and antifriction efficiency of the oil Mobil, apparently, one of the best in the world, the coincidence of antifriction properties of the compositions CNT and MS-20, presumably similar in preparation. Good antifriction properties confirmed nano diamond compositions CARATs. And CFG «Sarnowsky» revealed the best of serpentine and brings tribologist Russia's engine oil М-10Г2К SS class in the API, to the highest tribological properties of the oil company Mobil.

The mechanism of formation of serpentine by triboactive coatings are not academically not received. Their carbon films, diamond-like carbon (DLC) films, after the publication of the article-report of Chinese researchers [20], for the first time on 15.01.2009 at the conference in the companies «RUSNANO», was presented by scientist-biologist Pavlov O.G. Early versions about the nature of such coatings by the formation of cermet's, natural film sliding mirrors, diffusion of ionic components of powders in the friction surface and their unusual transformation to a depth of $1 \mathrm{~mm}$, as well as by micro metallurgical processes, formation of iron carbides. contradictory and do not correspond to the composition of coatings. However, the mechanism of formation of carbon tribocoatings from CFG in Pavlov's publications is not yet presented.

It generalizes the well-known domestic $[1,3-9,11,15,18]$, foreign [20-28] and identified [17] features locus-coatings. It is a high hardness (HV 1100-1850 kgf/cm2 [4]), resistance to etching solution of nitric acid [8], orange-gold color, coloring with fatsoluble dye SUDAN-B [15], resistance 10-12 Ohm/cm, carbon 
content up to $90 \%$ [20], the absence of CFG in the coating of the initial components [20], mirror purity ( $\mathrm{Ra} \approx 0.07 \mu \mathrm{m}$ [20]), damage by electricity, transparency, acceleration of formation with the introduction of carbon black at the suggestion of Pavlov O.G., further build-up and without CFG, and even dry.

Foreign studies on the creation and analysis of the properties of carbon tribotechnical coatings (Diamond-Like Carbon Films) [21-23], as well as a complex (24 articles) of their comprehensive studies [24] are analyzed. Studies of coatings based on compounds of car-bon atoms with hydrogen [25], carboxylic [26,27], diamond [28] coatings are also taken into account. But the main attention was paid to the studies of coatings from serpentine compositions, conducted in the tribology laboratory of Beijing Tsinghua University [20].

From the analysis of the data of all studies, it is assumed that at the beginning, when grinding CFG particles, their physical activation, physical and chemical transformations take place [17], they clean the friction surfaces and open the juvenile surfaces of crystals on them with the abrasive action of minerals. Further, as identified in n limited liability company «Lyubimov and the company» [15], the crystal is created of mineral stalagmite base (Figure 5), and on it, with the possible involvement tribalism [4], are Carbonatite (sp3) and tribological polymerization [20-24] components of the environment in the creation of a CFG coating.. In it, carbides, oxides and iron hydroxides are interspersed with wear products [20]. The calculated coating thickness according to Lyubimov D.N. $600 \mu \mathrm{m}$, and in the practice of company «Enion-Baltika» to 1000 microns.

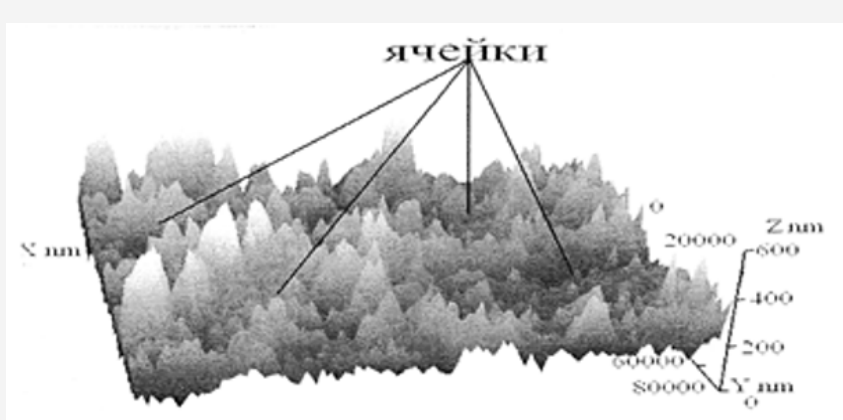

Figure 5: Topography of the sur-face after friction with serpentine $[9,15]$ : visible volume stalagmitic structure, grown on crystal planes of metals, on which grows a tribotechnical anti-friction coating.

We believe, that the increase in carbon-containing CFG coating, even in the subsequent absence of CFG, is due to the triboactivation of surfaces [3], as well as the extraordinary chemical activity of carbon atoms with their uncompensated surface bonds, the possibilities of sp1, sp2, sp3 hybridization [6], chemisorption of hydrocarbons of lubrication, and when working on dry interfaces according to the Institute of mechanics problems Russian Academy of Sciences, even carbon dioxide from the environment.

This, apparently, is confirmed by the pioneers of CFG (Pavlov O.G., Sokol S.A.) the fact of accelerating the growth of coatings at the input powder's blacksmith soot, the formation of the same carbon family of diamond-like films and CFG coatings nondiamond compositions and nanocarbon fibers produced in Russia, where the surfaces are formed tribar chain Me-C-C-C.

When CFG treatment from the exhaust tract of the internal combustion engine is increased steam and water (up to 1.5 liters for 5-10 minutes). This can be explained by the destruction of water-oil sludge in the exhaust tract of the ice by activated exhaust gases from the burned components of the CFG.

In the Tambov state University of VNIITiN was performed 250hour performance tests triboactive "Sarnowsky» in diesel engines of tractors MTZ-82, MTZ-1221и DT-75M. It was established the total reduction of fuel consumption of tractors at 5-8\%, of the waste engine oil by 10-12\%, and the opacity of exhaust gases by 8-15 $\%$. But most importantly - the iron content in motor oils decreased compared to the content in the previous period of work, also 250 hours, by 20-25\%. This indicated really anti-wear property of triboactive and increase of service life of the tested diesel engines, which once again confirmed the known from the beginning of 90ies. $[6-8,10,12-14,16-18]$ the effectiveness of CFG-technology.

\section{Conclusion}

The research results give reason to believe that $\mathrm{CFG}$ «Sarnowsky» from industrial waste containing major mineral Lizardite $1 \mathrm{~T}$, tribological satisfactory, and the possibility of creating a tribotechnical composition and the broad use of it from industrial waste is confirmed. The resulting CFG can be used to restore of efficiency of worn-out internal combustion engines, power transmissions.

The hypothesis of formation of the repair coating mating friction may assume: triboactivation particles $\mathrm{CFG}$, the opening of their juvenile surfaces of the crystals, physicochemical transformations and creation juvenile mineral surfaces stalagmite structures, and on it, with the possible involvement tribalism, the passage of carbonization and tribological polymerization of the components of a tribological environment. After removal of triboactive a further increase in coatings because of their own triboactivation and reactions of the extraordinary properties of carbon atoms.

\section{Acknowledgement}

None.

\section{Conflict of Interest}

No conflict of interest.

\section{References}

1. Vashenok AV, Kazarezov VV, Talovina IV, Kostenko VV (2002) Serpentini in tribotechnik// Mineralogiy, 1: 12-17.

2. Drozdov Yu N, Buyanovskii IA, Zelenskaya MN, Gostev VA, Novikov VI, et al. (2004) Novay protivoiznosnay i antifrikstionnay resursovosstanavlivaushay kompozitsiy prisadok $\mathrm{k}$ smazochnim materialam [New resursosnabzheniya anti-wear and anti-friction additive system for lubricants]//. Problemi mashinostroeniy i nadejnosti mashin $=$ Problems of engineering and reliability mashin 5: 50-53

3. Zuev VV (2005) Konstituzthiy i svoiystva mineralov i stroenie zemli [The minerals and earth structure], St.-Petersburg, Nauka Publ pp. 400.

4. Sokol SA, Dunaev AV (2011) Formirovanie katalizatorom «Evo®lution» $\mathrm{v}$ zone treniy almazopodobnih uglerodnih plenok [Formation by the 
catalyst «Evo®lution» in areas of friction diamond-like carbon films]// Trudy Mezhdunarodnoi konferenstii «Problemi sinergetiki v tribologii, triboelektohimii, materialovedenii i mehatronike» [Proceedings of the international conference «Problems sinergetiki in tribology, triboelectricity, material science and mechatronics], Novozherkassk, pp. 133-137.

5. Teluh DM, Kuzmin VP, Usachev VV Vvedenie (2009) v problemu ispolzovaniy prirodnih sloistih gidrosilicatov $\mathrm{v}$ tribosoprijeniyh [Introduction to the issue of the use of natural layered hydrosilicates in friction units]// Internet-gurnal «Trenie, iznos i smazka» [The Internetthe magazine «Friction, wear, lubrication»] 3: 13-17.

6. Lavrov Yu G (1997) Povishenie dolgovechnosti korabelnih dvigateley vvedeniem neor-ganicheskih prisadok prirodnogo proishojdeniy// Diss. kand. tehn. nauk [Increase of durability of ship engine by the introduction of inorganic additives of natural origin. Dr. tech. sci. diss.] $\mathrm{S}-\mathrm{Pb}, 288 \mathrm{p}$.

7. Shabanov A Yu (2004) Osherki sovremennoi avtohimii. Mifi ili realnost [Essays on modern chemistry, myth or reality]// St-Pbeterburg, ASPOL Publ, $216 \mathrm{p}$

8. (2008) «CIAM P.I. Baranov». Otchet No. 13505. Issledovanie vliyniy tribotehnicheskogo sostava «WL-Avia» na izmenenie svoistv osnovnih detalei dvigatelei semeistva M-14 na osnovanii rezultatov stendovih ispitaniy [Investigation of influence of tribological composition "WLAvia" to modify the properties of the main parts of the engine family M-14 based on the results of bench tests]// Moscow, «CIAM P.I Baranov», $35 \mathrm{p}$.

9. Lyubimov DN, Dolgopolov KN (2009) Struktura smazochnih sloev, formiruemih pri trenii v prisutstvii prisadok mineralnih modificatorov treniy [The structure of the lubricating layer, of for-miramich at friction in the presence of additives of mineral friction modifiers]// Trenie iznos = Friction and wear 5(30): 516-521.

10. Beliy IF, Merkulov AF, Beliy VI, Golubev IG (2011) Effektivnoe ispolzovanie antifrikztionnih dobavok $\mathrm{k}$ transmissionnim i motornim maslam [Efficient use of antifriction additivites to transmission and engine oils]// Moscow, Rosinformagroteh Publ, $52 \mathrm{p}$.

11. Vasilkov DV, Pustovoi IF, Pustovoy NI (2011) Analyz poverhnostnogo sloy, formiruemogo mineralnimi modifikatorami poverhnosti treniy [Analysis of surface layer formation mineral modifiers for the friction surface]// Trudy GOSNITI [Proceedings of GOSNITI] 107(2): 11-13.

12. Chechet VA (2011) Izbiratelniy sposob remonta agregatov mashin [Selective method of repair of units of cars]// Trudy GOSNITI [Proceedings of GOSNITI] 107(2): 34-37.

13. Pustovoy IF (2011) 14-letniy opit Piterskoy RVS-technologii [A 14year veteran of the St. Petersburg RVS-technology]// Trudy GOSNITI [Proceedings of GOSNITI] 107(2): 38-40.

14. Ostrikov VV, Busin IV, Popov SV (2012) Uvelichenie resursa rabotauzthego motornogo masla i povishenie ego protivoiznosnih svoistv [The increase of working resource of the engine oil and enhance its anti-wear properties]// Trudy GOSNITI [Proceedings of GOSNITI] 109(1): 81-84.

15. Dolgopolov KN, Potekha VL, Lyubimov DN (2013) Tribology geomodificirovannih smazochnih materialov: Monografia [Tribology geomodificators materials: monograph]// Grodno, GGAU Publ, 430 p.
16. Dunaev AV, Lyalyakin VP, Solovyev R Yu (2013) Technologicheskie rekomendaztii po povisheniu resursa agregatov traktorov remontnovosstanovitelnimi dobavkami $\mathrm{k}$ smazochnim maslam [Technological recommendations for increasing the resource units of the tractors repair and rehabilitation additives for oil lubricants]// Moscow, Rosinformagroteh Publ, 96 p.

17. Dunaev A., Sharifullin SN (2013) Modernizatziay iznoshennoi techniki c primeneniem tribopreparatov [Upgrading worn-out equipment with the use of triboadditives]// Kazan, Kazanski Univ. Publ, 272 p.

18. Lazarev SY (2016) 0 kontseptualnih voprosah issledovaniy v oblasti tribologii prirodnih mineralnih materialov [On conceptual questions of research in the field of tribology of natural mineral materials]// Trudy GOSNITI [Proceedings of GOSNITI] 124(2): 47-52.

19. Puzyr AP, et al. (2006) Perspektivi ispolzovaniy detonaztionnih nanoalmazov s povishennoy kolloidnoy ustoychivostyu $\mathrm{v}$ tehnicheskih oblastyah [Prospects of using detonation nanodiamonds with a high kolodny resistance in technical fields] $/ /$ Nanotehnika $=$ Nanotehnika 4(8): 96-95.

20. Yuansheng J, Shenghua L (2007) Superlubricity of in situ generated protective layer on worn metal surfaces in presence of Mg6Si4010(OH)8. In Book: Super-lubricity, edited by Ali Erdemir and Jean-Michel Martin. Elsevier, pp. 445-469.

21. Erdemir A, Eryilmaz OL (2007) Superlubricity in Diamondlike Carbon Films. In Book: Superlubricity, edited by Ali Erdemir and Jean-Michel Martin. Elsevier, pp. 253-272.

22. Makoto Kano (2015) Overview of DLC-Coated Engine Components. In Book: Coating Technology for Vehicle Applications. Sung Chul Cha. Ali Erdemir Editors. Springer International Publishing. Switzerland, pp. 3762.

23. Nagashima So, Moon Myoung Woon (2015) Diamond-Like Carbon Coatings with Special Wettability for Automotive Applications. In Book: Coating Technology for Vehicle Applications. Sung Chul Cha. Ali Erdemir Editors. Springer International Publishing, Switzerland, pp. 191-202.

24. (2008) Tribology of Diamond-Like Carbon Films. Fundamentals and Applications. Christophe Donnet-Ali Erdemir Editors. Springer Science + Business Media, LLC. 664 p.

25. Fontaine J, Donnet C (2007) Superlow Friction of a-C:H Films: Tribochemical and Rheological Effects. In Book: Superlubricity. Edited by Ali Erdemir and Jean-Michel Martin. Elsevier, pp. 273-294.

26. Freyman C, Zhao B, Chung YW (2007) Suppression of Moisture Sensitivity of Friction in Carbon-Based Coatings. In Book: «Superlubricity» Edited by Ali Erdemir and Jean-Michel Martin. pp. 295-310.

27. Street KW, Miyoshi Jr K, Vander Wal RL (2007) Application of Carbon Based Nano-Materials to Aeronautics and Space Lubrication. In Book: Superlubricity. Edited by Ali Erdemir and Jean-Michel Martin, pp. 311340.

28. De Barros Bouchet MI, Kano M (2007) Superlubricity of Diamond/ Glycerol Technology Applied to Automotive Gasoline Engines. In Book: Superlubricity. Edited by Ali Erdemir and Jean-Michel Martin, pp. 471492. 